\title{
Factors Analysis for E-Services Adoption in Jordan: A Technology Acceptance Study
}

\author{
Ja'afer AL-Saraireh $^{1} \&$ Mohammad Alnabhan ${ }^{2}$ \\ ${ }^{1}$ Applied Science University, Amman, Jordan \\ 2 Jerash University, Jerash, Jordan \\ Correspondence: Ja'afer AL-Saraireh, Applied Science University, Amman, 11931, Jordan. E-mail: \\ sarjaafer@yahoo.com
}

Received: March 18, $2014 \quad$ Accepted: April 2, $2014 \quad$ Online Published: May 5, 2014

doi:10.5539/mas.v8n3p192 URL: http://dx.doi.org/10.5539/mas.v8n3p192

\begin{abstract}
This work investigates the factors affecting the adoption and acceptance of e-services in Jordan. In which, requirements for successful e-services implementation is addressed, and significant barriers being faced by e-services users and developers are described. Results have indicated that ease of use, usefulness, credibility, self-efficacy and trust had positive effects on the e-services adoption in Jordan. However, risk and cost at the other spectrum had a significant negative effect. Outcomes of this research have drawn a number of practical implications achieving positive attitude towards e-services adoption and developing the employment of e-services applications. Such implications include; promoting its trust, decreasing the perceived risk and cost, overcoming services development obstacles, considering user's capability concerns and increasing the awareness of e-services usefulness and ease of use.
\end{abstract}

Keywords: TAM, perceived usefulness, e-service, ease of use, trust, risk

\section{Introduction}

E-services experience is considered as a continuous emerging interest among information system researchers. Hence, there have been many surveys conducted regarding the factors affecting successful acceptance of e-services, especially in developing countries (Pi et al., 2012). There have been a few localized and comparative studies regarding e-services adoption in Jordan. These studies indicated that less than 5 percent of clients in Jordan are using e-services. Although, Jordan has set up many initiatives focusing on access and usage of e-services, and a set of legal service utilization frameworks has been developed, still E-services adoption and usage is considered very slow (Al-gaith et al., 2010) and (Al-Shboul \& Alsmadi, 2010). Hence, understanding e-services adoption drivers and barriers among clients in Jordan becomes increasingly important for researchers, as well as for decision and policy makers (Alateyah et al., 2013). Accordingly, this research work was motivated by two key questions: (1) what are the factors affecting the e-services adoption among Jordanian residents? (2) what are the barriers and inhibitors causing slow adoption and usage of e-services?

The following section presents literature review, in which the conceptual model was developed and research hypotheses are then presented in section 3, in section 4, research method is presented, data analysis and results are presented in section 5 . The paper concludes in section 6 .

\section{Literature Review}

Technology acceptance model (TAM) is used to study the adoption of technology (Lule et al., 2012). In addition, TAM is used to analyze how external factors affect internal beliefs, attitudes, and aims (Davis, 1989). The perceived Usefulness (U) and perceived Ease of Use (EoU) are two factors effecting users attitude toward using technology (A). There are external variables effecting the usefulness and ease of use (Davis et al., 1992). TAM is presented in Figure 1. 


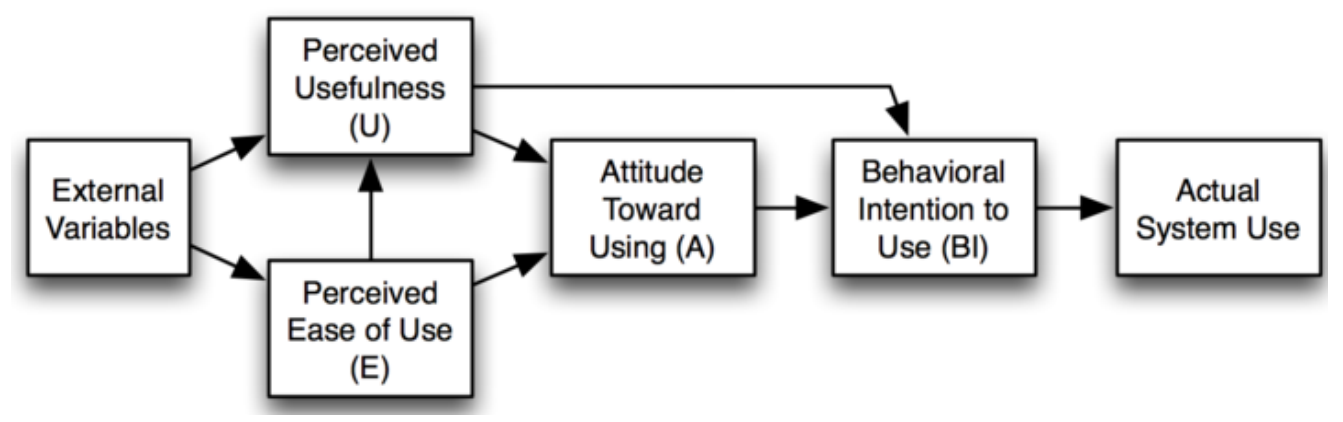

Figure 1. TAM (Davis, 1989)

Information Technology (IT) usage and adoption encompasses not only the simple use of hardware and software, but also the services that surround the IT, and the clients and procedures required for sustainability. E-service presents a singular chance to examine a user's interaction with a complex IT system (Alomari et al., 2012). The development of e-services and its adoption in Jordan has been recognized, and considered within the country's IT development vision. Jordan has embarked on two ambitious strategies that revolve around the development, deployment, and use of IT systems in Jordan.

The first strategy is a comprehensive plan to develop globally competitive software and IT service industry (Al-Shboul \& ALsmadi, 2010). The second plan requires endeavors to stimulate the development of the IT service industry through public- and private-sector collaboration (Alomari et al., 2012). Most significantly, both initiatives are planned to complement public-sector reform projects that can be traced to Jordan's attempt during the 1990s to implement (a) the National Information System (NIS) to support public decision makers, planners, and policy makers in decision-making activities (Abdel-Rahim, 1998) and (b) to allow public administration modernization (Jreisat, 1997). Despite the substantial increase in the number of Internet users in Jordan and the high demand in the IT products, there is no reading for potential growth of e-services. Drawing upon these literatures, this paper theoretically builds a model based on a modified of TAM by adding new variables as the independent variables. The modification of the model and the selection of variables are based on a scenario of Jordan and considering the fact that e-services is still at its early stage in Jordan. The main research issues are:

- Deciding on the drivers of Jordanian users to accept e-services and engage in the online transaction behavior.

- Deciding whether and how to integrating TAM under the nomological structure of Theory of Reasoned Action (TRA) to jointly predict clients' online behavior.

\section{Research Model and Hypothesis}

This work has addressed a set of variables affecting e-service adoption which are not described in the TAM. Hence, TAM should be modified relating to the specific nature and uniqueness of e-services adoption, in which new variables have been included in the model as indicated in Table 1. This study integrates TAM with five additional variables to examine the implementation of e-services as shown in Figure 2 and Table 1. The perceived Usefulness, perceived Ease of Use, attitude to use and adoption were retained according to TAM. In addition, variables such as Credibility, Self-Efficacy, Trust, and Transaction Cost were included in this study. 
Table 1. Descriptions of the constructs added to the original TAM

\begin{tabular}{|c|c|}
\hline Construct & Definition \\
\hline Behavioural Intention & $\begin{array}{l}\text { Refers to a person's intention to perform a behaviour and is a function of } \\
\text { Attitude and Perceived Usefulness (Lule et al., 2012) and (Davis, 1989). }\end{array}$ \\
\hline Attitudes & $\begin{array}{l}\text { Refers to individual's positive or negative evaluation of the behavior and is a } \\
\text { function of Perceived Usefulness and Perceived Ease of Use (Lule et al., } \\
\text { 2012) and (Davis, 1989). }\end{array}$ \\
\hline Perceived Ease of Use $\left(\mathrm{X}_{1}\right)$ & $\begin{array}{l}\text { Refers to person's beliefs that using a specific system would be free of effort } \\
\text { (Lule et al., 2012) and (Davis, 1989). }\end{array}$ \\
\hline Perceived Usefulness $\left(\mathrm{X}_{2}\right)$ & $\begin{array}{l}\text { Discusses to a person's belief that using a system would increase his work } \\
\text { performance (Lule et al., 2012) and (Davis, 1989). }\end{array}$ \\
\hline Perceived Risk $\left(\mathrm{X}_{3}\right)$ & $\begin{array}{l}\text { Touches to the possible to lose in the pursuance of a desired outcome of } \\
\text { utilizing e-services (Al-Shafi \& Weerakkody). }\end{array}$ \\
\hline Perceived Trust $\left(\mathrm{X}_{4}\right)$ & $\begin{array}{l}\text { Refers to the degree to which an individual has sufficient trust on the } \\
\text { particular to place an order online and still take his financial info and other } \\
\text { personal data in undertaking other financial transactions. }\end{array}$ \\
\hline Perceived Credibility $\left(\mathrm{X}_{5}\right)$ & $\begin{array}{l}\text { Refers to individual's behavioral intention to use the system. It contains } \\
\text { security and privacy (Lule et al., 2012) and (Luarn \& Lin, 2005). }\end{array}$ \\
\hline Perceived Transaction Cost $\left(\mathrm{X}_{6}\right)$ & $\begin{array}{l}\text { The transaction cost of using e-services (Luleet al., 2012) and (Luarn \& Lin, } \\
\text { 2005). }\end{array}$ \\
\hline Perceived Self-Efficacy $\left(\mathrm{X}_{7}\right)$ & $\begin{array}{l}\text { Means to the degree to which a person's trust in his capability to usage } \\
\text { e-services (Lule et al., 2012) and (Bandura, 1982). }\end{array}$ \\
\hline
\end{tabular}

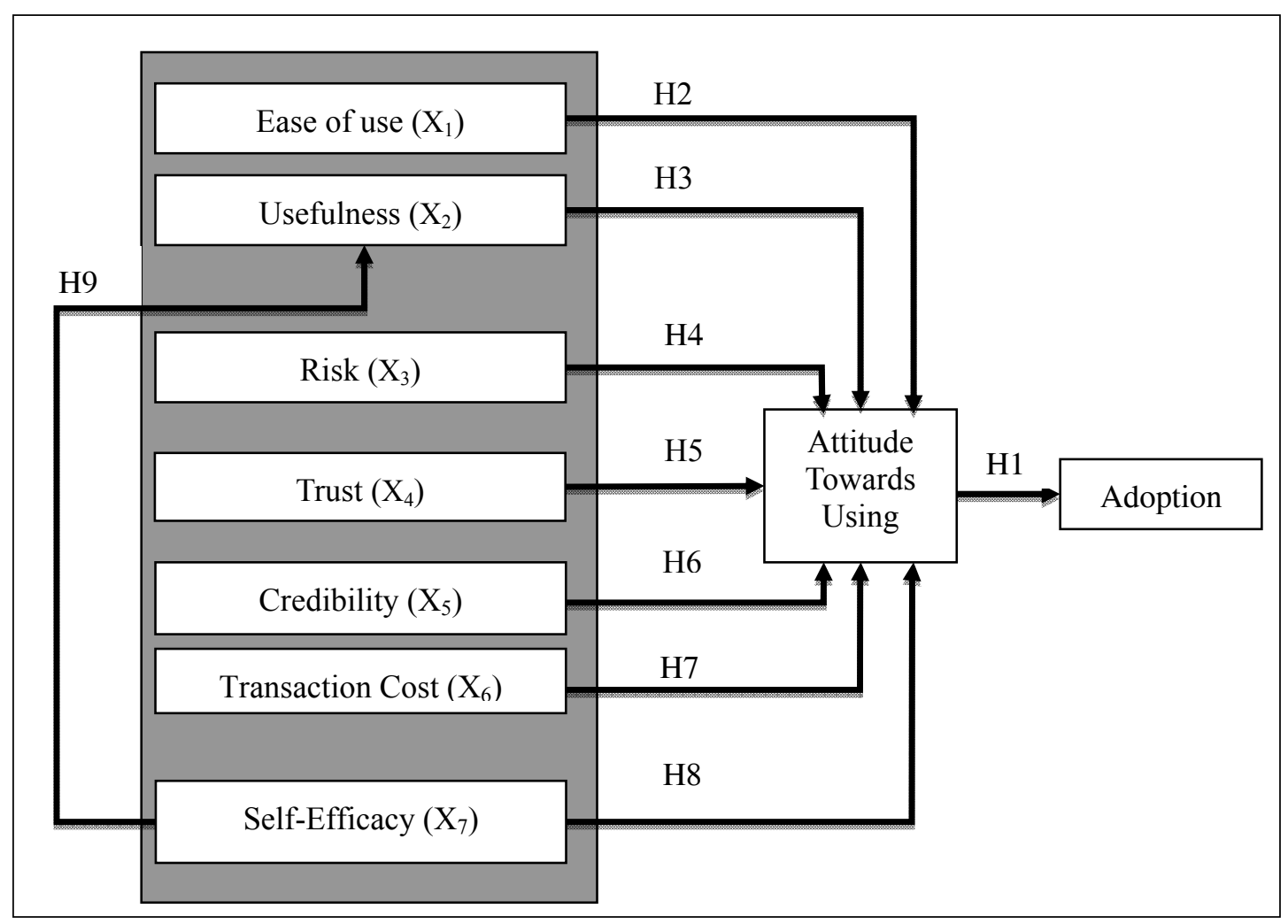

Figure 2. Proposed e-services adoption model 


\subsection{Attitude towards Using E-services (ATU)}

TAM assumes that individuals' use of e-services is influenced by individual's intention to use such services, $X_{1}$ and $X_{2}$ can predict the usage intention, and $X_{1}$ is hypothesized as a predictor of $X_{2}$. Transacting with e-services system requires the user to apply to this proposed scheme. Granting to the original TAM, it is anticipated that $\mathrm{X}_{1}$ and $\mathrm{X}_{2}$ of the scheme would be positively linked to the intention to transact with the system. Accordingly, the following hypotheses are presented:

H1: Individuals' attitude to employ e-services has no effect on behavioral intention to apply.

H2: Usefulness has no effect on attitude to employ e-services.

H3: Ease of use has no effect on attitude to employ e-services.

\subsection{Perceived Risk $\left(X_{3}\right)$}

The potential of being unsure about the certainty and accuracy of e-services transaction results, described as the perceived risk, will affect the clients' intention to transact with e-services system (Stone \& Gronhaug, 1993). The original TAM tends to concentrate on the positive prospects of technology $\left(\mathrm{X}_{1}\right.$ and $\left.\mathrm{X}_{2}\right)$. This weakens the explanatory power of TAM in circumstances where users' perceived risk degrades the system use. Accordingly, the following hypothesis is presented:

H4: The perceived risk has a significant negative effect on behavioral intention to use e-services.

\subsection{Perceived Trust $\left(X_{4}\right)$}

Various researchers have presented trust as an important component of e-services. It is believed that Trust creates positive attitudes and perceived behavioral control toward e-services, reducing uncertainty and providing expectations for a satisfactory transaction, thus positively influencing client behavioral intentions to transact. Hence, the following hypothesis is considered:

H5: The perceived trust will have a positive effect on attitude to employ e-services.

\subsection{Perceived Credibility $\left(X_{5}\right)$}

Credibility consists of privacy and security. Security is the protection of information from unauthorized users (Nysveen et al, 2005) and (Lule et al., 2012). Lack of security is one of the elements holding back the growth and development of e-services adoption. Hence, the following hypothesis is considered:

H6: Perceived credibility will have a negative effect on behavioral intention to utilize e-services.

\subsection{Perceived Transaction Cost $\left(X_{6}\right)$}

Transaction Cost is an essential factor that effect using e-services. If this factor is considered satisfactory for e-services users', then they are more likely to take and practice it (Lule et al., 2012). The transaction cost may prevent many users from choosing e-services. The following hypothesis is being considered:

H7: Transaction cost will have a positive effect on behavioral intention to utilize e-services.

\subsection{Perceived Self Efficacy $\left(X_{7}\right)$}

The Self Efficacy is an important factor in the adoption of e-services. Many research studies (Nysveen et al., 2005), (Wang et al., 2003) and (Mathioeson et al., 2004) have confirmed the significance of $X_{7}$ in technology acceptance. In these studies, $X_{7}$ affect the $X_{1}$ and assume that individuals' with higher degrees of $X_{7}$, will be more positive towards using e-services than others. Accordingly, the following hypotheses are considered:

H8: Self Efficacy has negative effect on attitude to the use e-services.

H9: Self Efficacy has negative effect on perceived ease of use of e-services

\section{Research Methodology}

The purpose of this work is to contribute to the extension of TAM within e-services context. Hence, attempts were made to prevent the research method from being similar to that employed by earlier studies on TAM (Gefen \& Straub, 2004; Pavlou, 2003; Men et al., 2011). However, as noted above, the modification of the model and the selection of variables are based on Jordanian users' requirements and considering the fact that e-service in Jordan is yet in its early phase.

\subsection{The Research Instrument}

This research was conducted using a set of qualified and comprehensive questionnaire consisting of three main sections. The first section contained basic demographic characteristics including gender, age, measures for 
assessing the degree of Internet usage, e-service's experience. In the second section, respondents were required to indicate the level of their risk, perception relative to the use of e-services. In the third part, the study participants were required to reply to inquiries on the other constructs of the model. For each section, Likert scale of five-point was employed.

\subsection{Sample}

The questionnaire was sent to 300 survey participants. In which, 265 replies were received with a response rate more than $80 \%$, of which 261 completed and 4 uncompleted questionnaires were received.

\subsection{Data Collection}

The research work concentrated on how to measure factors contributing to e-services adoption from the users' perspective; based on their experience, requirements and intellect. The data needed for fulfilling this purpose was obtained using a quantitative approach. A survey questionnaire was chosen as the most appropriate research strategy in this work. In which, the collection of information from a large population was considered.

\section{Results and Discussion}

\subsection{Descriptive Statistics}

As noted above, 265 questionnaires were returned from study participants. Using relatively large sample size and hatching a can measure the external validity of the survey. Table 2 lists the sample demographics.

The data indicated that $77.8 \%$ of respondents are from the age group of (19-23) years. This was because young people are more likely to use the internet than older people in Jordan, according to the statistics of Jordan National Information Center in 2005. In addition, it is shown that female respondents have a higher percentage (58.3\%) compared to male respondents. There are more respondents $(95 \%)$ who have e-mail address and most of the respondents have Internet Access (88\%). In addition, (75.1\%) of the respondents have their internet connection from home. Lastly, and in terms of using e-services transaction, only (14.9\%) of the respondents had online service experience. This conforms with previous research studies (Ment et al., 2011; Alghamdi et al., 2011; Yonazi et al., 2010; Colesca, 2009; Alawadhi \& Morris, 2009; Zarmpou et al., 2011) which indicated that users are more comfortable in accepting and using new technology innovations, when they have prior related experience, which might be the case with Jordanian users. However, it is the purpose of this research to recover out the factors and barriers affecting such a low adoption rate of e-services transaction.

Table 2. Demographic attributes of the responders

\begin{tabular}{lccc}
\hline \multicolumn{1}{c}{ Description } & Variable & Result & Percentage \\
\hline \multirow{2}{*}{ Gender } & Male & 109 & $41.7 \%$ \\
& Female & 152 & $58.3 \%$ \\
\hline \multirow{3}{*}{ Age } & $19-23$ years & 203 & $77.8 \%$ \\
& $24-28$ & 34 & $13 \%$ \\
& $29-33$ & 8 & $3.1 \%$ \\
\multirow{2}{*}{ Have an email } & Up to 30 & 16 & $6.1 \%$ \\
address & Yes & 248 & $95 \%$ \\
\hline \multirow{2}{*}{ Internet Access } & No & 13 & $5 \%$ \\
\hline \multirow{2}{*}{ Connect to the } & Yes & 230 & $88 \%$ \\
Internet & No & 31 & $12 \%$ \\
& Home & 196 & $75.1 \%$ \\
Used the internet & Office & 46 & $17.6 \%$ \\
for e-services & Internet Café & 19 & $7.3 \%$ \\
\hline
\end{tabular}




\subsection{Reliability and Validity}

To ascertain the reliability and strength of the survey, some measures are used when a questionnaire is designed. The reliability of the items is evaluated by Cronbach's alpha (Cronbach, 1951). Table 3 shows the results of the validity and reliability, representing suitable reliability.

Table 3. Reliability and validity analysis

\begin{tabular}{lcc}
\hline Construct & $\begin{array}{c}\text { \# of Items } \\
\text { (Questions in } \\
\text { Questioners) }\end{array}$ & Reliability \\
\hline Adoption $\left(\mathrm{Y}_{1}\right)$ & 3 & 0.765 \\
Attitudes Toward & 5 & 0.724 \\
Using $\left(\mathrm{Y}_{2}\right)$ & & \\
Ease of Use $\left(\mathrm{X}_{1}\right)$ & 4 & 0.797 \\
Usefulness $\left(\mathrm{X}_{2}\right)$ & 5 & 0.783 \\
Risk $\left(\mathrm{X}_{3}\right)$ & 4 & 0.782 \\
Trust $\left(\mathrm{X}_{4}\right)$ & 4 & 0.747 \\
Credibility $\left(\mathrm{X}_{5}\right)$ & 4 & 0.737 \\
Transaction Cost $\left(\mathrm{X}_{6}\right)$ & 4 & 0.756 \\
Self-Efficacy $\left(\mathrm{X}_{7}\right)$ & 4 & 0.771 \\
\hline
\end{tabular}

Table 4. Correlation between Latent variables $\left({ }^{*} 10^{-2}\right)$

\begin{tabular}{|c|c|c|c|c|c|c|c|c|c|c|}
\hline Variable & & $\mathrm{X}_{1}$ & $\mathrm{X}_{2}$ & $\mathrm{X}_{3}$ & $\mathrm{X}_{4}$ & $\mathrm{X}_{5}$ & $\mathrm{X}_{6}$ & $\mathrm{X}_{7}$ & $\mathrm{Y}_{2}$ & $\mathrm{Y}_{1}$ \\
\hline \multirow{4}{*}{$\mathrm{X}_{1}$} & Q1 & 63 & 17 & 15 & 08 & 20 & 07 & 22 & 34 & 22 \\
\hline & Q2 & 75 & 14 & 22 & 06 & 13 & 13 & 18 & 22 & 24 \\
\hline & Q3 & 72 & 16 & 11 & 10 & 17 & 17 & 15 & 26 & 25 \\
\hline & Q4 & 68 & 18 & 12 & 09 & 18 & 10 & 12 & 18 & 23 \\
\hline \multirow{5}{*}{$X_{2}$} & Q1 & 24 & 72 & 21 & 12 & 21 & 17 & 11 & 17 & 24 \\
\hline & Q2 & 26 & 65 & 14 & 17 & 14 & 14 & 11 & 12 & 21 \\
\hline & Q3 & 22 & 75 & 09 & 21 & 09 & 12 & 17 & 09 & 14 \\
\hline & Q4 & 18 & 62 & 18 & 08 & 18 & 21 & 19 & 10 & 09 \\
\hline & Q5 & 19 & 68 & 19 & 09 & 19 & 15 & 21 & 12 & 18 \\
\hline \multirow{4}{*}{$X_{3}$} & Q1 & 23 & 19 & 56 & 11 & 15 & 23 & 14 & 21 & 19 \\
\hline & Q2 & 37 & 23 & 67 & 18 & 09 & 19 & 09 & 18 & 27 \\
\hline & Q3 & 19 & 21 & 58 & 09 & 18 & 21 & 18 & 21 & 17 \\
\hline & Q4 & 24 & 16 & 69 & 12 & 21 & 17 & 19 & 23 & 08 \\
\hline \multirow{4}{*}{$\mathrm{X}_{4}$} & Q1 & 08 & 14 & 32 & 72 & 23 & 08 & 17 & 16 & 19 \\
\hline & Q2 & 09 & 21 & 27 & 64 & 16 & 09 & 16 & 29 & 09 \\
\hline & Q3 & 15 & 08 & 16 & 53 & 28 & 17 & 09 & 21 & 09 \\
\hline & Q4 & 09 & 11 & 18 & 58 & 17 & 12 & 18 & 08 & 18 \\
\hline \multirow{4}{*}{$\mathrm{X}_{5}$} & Q1 & 07 & 15 & 21 & 11 & 56 & 09 & 14 & 19 & 18 \\
\hline & Q2 & 16 & 09 & 15 & 08 & 62 & 10 & 09 & 17 & 21 \\
\hline & Q3 & 21 & 12 & 09 & 19 & 57 & 12 & 18 & 21 & 23 \\
\hline & Q4 & 15 & 18 & 18 & 13 & 64 & 21 & 19 & 08 & 16 \\
\hline \multirow{4}{*}{$X_{6}$} & Q1 & 18 & 15 & 21 & 27 & 18 & 69 & 19 & 29 & 21 \\
\hline & Q2 & 05 & 19 & 23 & 24 & 15 & 72 & 23 & 21 & 21 \\
\hline & Q3 & 12 & 21 & 16 & 31 & 09 & 70 & 33 & 18 & 14 \\
\hline & Q4 & 14 & 07 & 21 & 13 & 18 & 69 & 21 & 19 & 09 \\
\hline \multirow{4}{*}{$X_{7}$} & Q1 & 09 & 17 & 23 & 18 & 21 & 19 & 62 & 21 & 18 \\
\hline & Q2 & 13 & 12 & 21 & 22 & 23 & 14 & 54 & 18 & 19 \\
\hline & Q3 & 14 & 09 & 15 & 19 & 16 & 18 & 56 & 25 & 15 \\
\hline & Q4 & 09 & 10 & 19 & 17 & 21 & 21 & 54 & 21 & 17 \\
\hline \multirow{5}{*}{$\mathrm{Y}_{2}$} & Q1 & 17 & 12 & 18 & 16 & 23 & 21 & 17 & 54 & 12 \\
\hline & Q2 & 19 & 21 & 23 & 21 & 21 & 14 & 12 & 56 & 09 \\
\hline & Q3 & 21 & 24 & 26 & 25 & 17 & 09 & 09 & 61 & 10 \\
\hline & Q4 & 18 & 26 & 21 & 21 & 16 & 18 & 10 & 58 & 12 \\
\hline & Q5 & 23 & 19 & 16 & 24 & 18 & 19 & 12 & 60 & 21 \\
\hline \multirow{3}{*}{$Y_{1}$} & Q1 & 17 & 15 & 19 & 19 & 21 & 21 & 21 & 19 & 80 \\
\hline & Q2 & 18 & 17 & 23 & 16 & 09 & 08 & 14 & 18 & 78 \\
\hline & Q3 & 13 & 16 & 26 & 21 & 17 & 15 & 09 & 15 & 79 \\
\hline
\end{tabular}


Convergent validity is considered to confirm that each item correlates to hypothetical assumption, validity needs to fit within Average Variance Extracted (AVE) (Lule et al., 2012). This validity is extended out to determine that square base of AVE should be higher than any correlation between any couple of latent variables. The correlation between latent variable and AVE are represented in Tables 4 and 5.

Table 5. AVE ad Square Root AVE

\begin{tabular}{lcc}
\hline Variables & AVE*10 & Square Root AVE $* 10^{-3}$ \\
\hline $\mathrm{X}_{1}$ & 655 & 764 \\
$\mathrm{X}_{2}$ & 694 & 798 \\
$\mathrm{X}_{3}$ & 543 & 675 \\
$\mathrm{X}_{4}$ & 672 & 714 \\
$\mathrm{X}_{5}$ & 581 & 636 \\
$\mathrm{X}_{6}$ & 723 & 758 \\
$\mathrm{X}_{7}$ & 623 & 670 \\
$\mathrm{Y}_{2}$ & 427 & 625 \\
$\mathrm{Y}_{1}$ & 783 & 875 \\
\hline
\end{tabular}

\subsection{Model Validity and Hypotheses Testing}

A various modifications for proposed model are carried out by analysis test. Table 6 , presents the fit measures for the proposed model. The overall fit for Chi-Square/Degree Freedom for Model (CSM/DFM) is 2.615 (less than 3) significant and $\mathrm{P}$ value 0 .

Table 6. Fit measures of the proposed model

\begin{tabular}{|c|c|c|}
\hline Fit Measures & Standards Fit & Model Fit \\
\hline Chi-Square for Model (CSM) & & 81.350 \\
\hline Degree Freedom for Model (DFM) & & 29.734 \\
\hline $\begin{array}{lll}\text { Chi-Square/Degree } & \text { Freedom } & \text { for } \\
\text { Model (CSM/DFM) } & & \end{array}$ & $\begin{array}{l}\text { Fit when value approximately }=1 \\
\text { and } \leq 3 \text { fit. }\end{array}$ & 2.736 \\
\hline Incremental Fit Index (IFI) & Fit when value approximately $=1$ & 0.871 \\
\hline Tucker-Lewis Index (TLI) & Fit when value approximately $=1$ & 0.867 \\
\hline Normed Fit Index (NFI) & Fit when value approximately $=1$ & 0.852 \\
\hline Comparative Fit Index (CFI) & Fit when value approximately $=1$ & 0.893 \\
\hline Relative Fit Index (RFI) & Fit when value approximately $=1$ & 0.826 \\
\hline $\begin{array}{l}\text { Root Mean-Square Error of } \\
\text { Approximation (RMSEA) }\end{array}$ & Fit when value $\leq 0.1$ & 0.078 \\
\hline
\end{tabular}

\subsection{Hypotheses Analyses}

Analysis of variance (ANOVA) is applied to examine the proposed theories. The results in Table 7 represent the test hypothesis by using ANOVA, based on the significant level of (0.05). The hypothesis is accepted if the significance level was more than (0.05).

To determine the relationships among the variables, $\beta$ is very important as it compares the contribution of each independent variable for explaining the dependent variable. A large value indicates that a unit change in this predictor or independent variable has a large effect on the dependent variable. The $t$ and Sig (p) values give a rough indication for the impact of each predictor variable, a big absolute $t$ value $>3$ and small $\mathrm{p}$ value $\leq 0.05$, suggests that a predictor variable is having a large impact on the criterion variable (Hair et al., 2005). 
As a result, in Table 7, the variance in e-services adoption accounted by user's attitude is $8.2 \%$, the $t$ value is 14.2 , and the $\mathrm{H} 1$ is rejected because $\mathrm{t}$ value is greater than 0.05 . This pointed out that user's attitude to use e-services affects the behavioral intention to use. In addition, Table 7 shows that $9.5 \%$ of the variance in user perspective of e-services adoption accounted by easy to use, the $\mathrm{t}$ value is 15.3 , hence $\mathrm{H} 2$ is rejected because $\mathrm{t}$ value is greater than 0.05 . This indicates that usefulness has a direct effect on using e-services. In addition, results has described $8.4 \%$ disagreement in user viewpoint towards e-services usefulness, the t value is 14.4, hence $\mathrm{H} 3$ is rejected because $\mathrm{t}$ value is greater than 0.05 . This point indicated that the ease of use has a substantial influence on attitude to use e-services.

The correlation between perceived risk and intention to use e-services (H4), is also supported ( $\beta: 2.1 \%, \mathrm{t}: 12.2$, sig: 0:000). This implies that if the users consider using e-services is risky, the intention to e-services adoption will be low. H5, measures the correlation between the trust and the intention of using e-services, is supported ( $\beta$ : $8.3 \%$, t: 14.5 sig: 0:000). This indicates that if the users consider using e-services is trustworthy, the intention of e-services adoption will be high. H6, which indicates perceived credibility will have a negative effect on behavioral intention to utilize e-services, ( $\beta: 8.1 \%$, t: 14.1 sig: $0: 000)$. H6 is rejected because $\mathrm{t}$ value is greater than 0.05 . Moreover, $2.3 \%$ of the variance in user perspective of e-services adoption is accounted by cost, the $t$ value is 11.2 , and the $\mathrm{H} 7$ is rejected because $\mathrm{t}$ value is greater than 0.05 . This confirms that there is an effect of cost on e-services adoption, this result is supported by previous studies. At last, perceived credibility and Self Efficacy has an important influence on attitude to the use e-services. Therefore, $\mathrm{H} 8$ and $\mathrm{H} 9$ are rejected because $\mathrm{t}$ value is greater than 0.05 .

Table 7. Summary of the regression results and test of hypotheses

\begin{tabular}{ccccccc}
\hline Hypotheses & $\begin{array}{c}\text { Independent } \\
\text { Variables }\end{array}$ & Dependent variables & B & T & Sig p & Support \\
\hline H1 & $\begin{array}{c}\text { User's attitude to } \\
\text { use e-services } \\
\text { Ease of use }\end{array}$ & Intention to Usage & 0.082 & 14.2 & 0.00 & Yes \\
H2 & $\begin{array}{c}\text { Attitude to Use E-Services } \\
\text { H3 }\end{array}$ & 0.095 & 15.3 & 0.00 & Yes \\
Usefulnes & Attitude to Use E-Services & 0.084 & 14.4 & 0.00 & Yes \\
H4 & $\begin{array}{c}\text { Perceived Risk } \\
\text { Perceived } \\
\text { H5 }\end{array}$ & Attitude to use E-Services & 0.021 & 12.2 & 0.00 & Yes \\
Trust & Attitude to Use E-Services & 0.083 & 14.5 & 0.00 & Yes \\
H6 & $\begin{array}{c}\text { Perceived } \\
\text { Credibility }\end{array}$ & Attitude to Use E-Services & 0.081 & 14.1 & 0.00 & Yes \\
H7 & $\begin{array}{c}\text { Perceived } \\
\text { Cost }\end{array}$ & Attitude to Use E-Services & 0.023 & 11.2 & 0.00 & Yes \\
H8 & $\begin{array}{c}\text { Perceived } \\
\text { Self-Efficacy } \\
\text { Perceived }\end{array}$ & Attitude to Use E-Services & 0.078 & 13.8 & 0.00 & Yes \\
H9 & Self-Efficacy & Ease of Use E-Services & 0.076 & 13.6 & 0.00 & Yes \\
\hline
\end{tabular}

\section{Conclusion}

This research work has described a theoretical model for investigating factors influencing Jordanian clients' adoption of e-services. These factors correspond to a set of hypotheses used to determine the pertinence of the theoretical model. E-services successful implementation was determined by users' behavior while dealing with electronic arrangements being experienced during the evaluation study. An intensive questionnaire was used within the evaluation study and ANOVA statistical analysis was used to confirm or reject the proposed model hypothesis. Results have described major e-services adoption and acceptance determinants. In addition, empirical results explain interesting insights into factors affecting users' intention toward e-services adoption, taking into consideration Jordanian users' requirements. It was measured that that ease of use, usefulness, credibility, self-efficacy and trust had positive effects on the e-services adoption in Jordan. However, e-services 
deployment risk and utilization cost have a negative influence towards using and adopting e-services. In addition, users' capability including self efficiency is significantly related to perceived usefulness and ease of use.

Based on these conclusions, the successful adoption of e-services in Jordan implies considering more attention on cost, security and information privacy. In addition, user's capability concerns and preferences, are required to be addressed while designing and developing e-services. The awareness and understanding of e-services needs to be increased and new policies needs to be adopted allowing for an simple transition from tradition to digital systems.

\section{References}

Abdel-Rahim, S. (1998). The impact of the information revolution on society and state in Jordan. The information revolution and the Arab World (pp. 160-175).

Alateyah, S., Crowder, R., \& Wills, G., (2013). An Exploratory study of proposed factors to Adopt e-government Services Saudi Arabia as a case study. International Journal of Advanced Computer Science and Applications, 4(11), 57-66.

AlAwadhi, S., \& Morris, A. (2009). Factors influencing the adoption of e-government services. Journal of Software, 4, 584-590.

Al-Ghaith, W., Sanzogni, L., \& Sandhu, K. (2010). Factors Influencing The Adoption And Usage Of Online Services In Saudi Arabia. The Electronic Journal on Information Systems in Developing Countries EJISDC, 40(1), 1-32.

Alghamdi, I., Goodwin, R., \& Rampersad, F. (2011). E-government readiness assessment for government organizations in developing countries. Computer and Information Science, 4, 3-17. http://dx.doi.org/10.5539/cis.v4n3p3

Alomari, M. K., Woods, P., \& Sandhu, K. (2012). Predictors for e-government adoption in jordan: Deployment of an empirical evaluation based on a citizen-centric approach. Information Technology \& People, 25(2), 207-234. http://dx.doi.org/10.1108/09593841211232712

Al-Shafi, S., \& Weerakkody, V. (2010). Factors affecting e-government adoption in the state of Qatar. European and Mediterranean Conference on Information Systems (Emcis) (pp. 1-23). Abu Dhabi, UAE, April 12-13 (2010).

Al-Shboul, M., \& Alsmadi, I. (2010). Jordan E-Government Challenges and Progresses. International Journal of Advanced Cooperating Learning, 3(1), 37-41.

Bandura, A. (1982). Self-Efficacy mechanism in Human Agency. American Psychologist, 37(2), 122-147. http://dx.doi.org/10.1037/0003-066X.37.2.122

Colesca, S. E. (2009). Increasing e-trust: A solution to minimize risk in e-government adoption. Journal of Applied Quantitative Methods, 4, 31-44.

Cronbach, L. J. (1951). Coefficient alpha and the internal structure of tests. Psychometrika, 16, 297-333. http://dx.doi.org/10.1007/BF02310555

Davis, F. D. (1989). Perceived Usefulness, Perceived Ease of Use, and User Acceptance of Information Technology. MIS Quarterly, 13(3), 319-339. http://dx.doi.org/10.2307/249008

Davis, F. D., Bagozzi, R. P., \& Warshaw, P. R. (1992). Extrinsic and Intrinsic Motivation to Use Computers in the Workplace. Journal of Applied Social Psychology, 22(14), 1111-1132. http://dx.doi.org/10.1111/j.1559-1816.1992.tb00945.x

Gefen, D., \& Straub, D. W. (2004). Consumer Trust in B2C e-Commerce and the Importance of Social Presence: Experiments in e-2 Products and e-Services. Omega: The International Journal of Management Science, $32(6), 407-424$.

Hair, J. F. (2005). Multivariate data analysis. Upper Saddle River: Pearson, Prentice Hall.

Jreisat, J. E. (1997). Politics without process: Administering Development in the Arab World. Lynne Rienner Publishers.

Luarn, P., \& Lin, H. H. (2005). Toward an understanding of the behavioral intention to use mobile banking. Computers in Human Behavior, 21, 873-891. http://dx.doi.org/10.1016/j.chb.2004.03.003

Lule, I., Omwansa, T., \& Waema, M. (2012). Application of Technology Acceptance Model (TAM) in M-Banking Adoption in Kenya. International Journal of Computing and ICT Research, 6(1), 31-43. 
Mathieson, K., Peacock, E., \& Chin., W. W. (2001). Extending the technology acceptance model: The influence of perceived user resources. Data Base for Advances in Information Systems, 32(3), 86-112. http://dx.doi.org/10.1145/506724.506730

Nysveen, H., Pedersen, P. E., \& Thorbjornsen, H. (2005). Intentions to Use Mobile Services: Antecedents and Cross-Service Comparisons. Journal of the Academy of Marketing Science, 33(3), 330-346. http://dx.doi.org/10.1177/0092070305276149

Pavlou, P. A. (2003). Consumer Acceptance of Electronic Commerce: Integrating Trust and Risk with the Technology Acceptance. International Journal of Electronic Commerce, 7(3), 101-134.

Pi, S. M., Liao, H. L., \& Chen, H. M. (2012). Factors that affect consumers' trust and continuous adoption of online financial services. International Journal of Business and Management, 7, 108-119. http://dx.doi.org/10.5539/ijbm.v7n9p108

Seng Wong, M., Hideki, N., \& George, P. (2011). The use of importance-performance analysis (ipa) in evaluating japan's e-government services. Journal of Theoretical and Applied Electronic Commerce Research, 6, 17-30.

Stone, R. N., \& Gronhaug, K. (1993). Perceived Risk: Further Considerations for the Marketing Discipline. European Journal of Marketing, 27(3), 39-50. http://dx.doi.org/10.1108/03090569310026637

Taylor, S., \& Todd, P. (1995). Assessing IT Usage: The Role of Prior Experience. MIS Quarterly, 19(4), 561-570. http://dx.doi.org/10.2307/249633

Wang, Y. S., Wang, Y. M., Lin, H. H., \& Tang, T. I. (2003).Determinants of user acceptance of internet banking: An empirical study. International Journal of Service Industry Management, 14(5), 501-519. http://dx.doi.org/10.1108/09564230310500192

Yonazi, J., Sol, H., \& Boonstra, A. (2010). Exploring issues underlying citizen adoption of e-government initiatives in developing countries: The case of Tanzania. Electronic Journal of e-Government, 8, 176-188.

Zarmpou, T., Saprikis, V., \& Vlachopoulou, M. (2011). Examining Behavioral Intention toward Mobile Services: An Empirical Investigation in Greece. International Journal of E-Services and Mobile Applications, 3(2), 1-19. http://dx.doi.org/10.4018/jesma.2011040101

\section{Copyrights}

Copyright for this article is retained by the author(s), with first publication rights granted to the journal.

This is an open-access article distributed under the terms and conditions of the Creative Commons Attribution license (http://creativecommons.org/licenses/by/3.0/). 